\title{
Painless Thyroiditis Presenting as Hypercalcemia in Pregnancy: A Rare Case Report
}

\author{
Homaid Alsahafi, Bandar Damanhuri, Faizal Ahmed, Faisal Almalki, Dhyaa Mokhtar \\ Department of Endocrinology \& Diabetology, Hera General Hospital, Makkah, Saudi Arabia.
}

\begin{abstract}
The evaluation and treatment of pregnant women with thyrotoxicosis parallels that of nonpregnant women and men, but presents some unique problems. Painless thyroiditis is a very rare cause of thyrotoxicosis in pregnancy. In our report we present a case of painless thyroiditis in a 31 years pregnant woman old presenting with hypercalcemia in pregnancy.
\end{abstract}

Keywords: Painless Thyroiditis, Hypercalcemia, Thyrotoxicosis.

Article History:

Received: 03-11-2016, Revised: 17-11-2016, Accepted: 28-11-2016

\section{${ }^{*}$ Correspondence to:}

Homaid Alshafi

Department of Endocrinology \& Diabetology,

Hera General Hospital,

Makkah, Saudi Arabia.

\begin{tabular}{|l|c|}
\hline \multicolumn{2}{|c|}{ Access this article online } \\
\hline $\begin{array}{l}\text { Website: } \\
\text { www.ijmrp.com }\end{array}$ & \\
\hline DOl: & \\
10.21276/ijmrp.2016.2.6.033 & \\
\hline
\end{tabular}

\section{INTRODUCTION}

Hyperthyroxinemia during pregnancy is relatively uncommon. Approximately 1 or 2 out of 1000 pregnancies will be complicated by hyperthyroidism. ${ }^{1}$ The major causes of thyrotoxicosis in women of child bearing age is Graves' disease. ${ }^{2}$ Painless thyroiditis is a disease causing thyrotoxicosis during the postpartum period. ${ }^{3}$ It is characterized by transient thyrotoxicosis, followed sometimes by hypothyroidism, and then recovery. ${ }^{4}$ In our literature search we found only one case of painless thyroiditis presenting in pregnancy and no cases of painless thyroiditis presenting with hypercalcemia in pregnancy.

\section{CASE REPORT}

31 year old female Gravida 4 Para $3+0$ in her $20^{\text {th }}$ week of gestation presented to Emergency Room (ER) with history of progressive fatigue and vomiting for 14 days. Upon arrival, she was pale, cachectic, conscious, and drowsy with Glasgow coma scale of $13 / 15$. Her vitals were stable with pulse rate of 114 per minute and regular. General and systemic examination was unremarkable.

On day 1, Plane computerized tomography (CT) brain was done in the Emergency room (with precautions) which came back normal. Initial essential blood work showed; Hemoglobin $9.8 \mathrm{mg} / \mathrm{dl}$, Platelet 299, White blood cells 20 , serum creatinine $1.8 \mathrm{mg} / \mathrm{dl}$, Urea $74 \mathrm{mg} / \mathrm{dl}$, serum potassium $3.2 \mathrm{mmol} / \mathrm{L}$, serum sodium 132 $\mathrm{mmol} / \mathrm{L}$, and the patient was admitted to the intensive care unit for further management.

A full blood work showed: serum calcium $18.8 \mathrm{mg} / \mathrm{dl}$, serum albumin $2.4 \mathrm{mg} / \mathrm{dl}$, serum magnesium 1.6, serum phosphate 4.2 , serum chloride 106 , serum aspartate transaminase 90 , serum alanine transaminase 24 , serum alkaline phosphate 2.3 , serum bilirubin (total 0.8 , Direct 0.7 ) serum amylase 925 , creatnine kinase 25, serum thyroid stimulating hormone (TSH) 0.005 , serum free thyroxin (FT4) 394, serum free triiodothyronine (FT3) 21,serum parathyroid hormone (PTH) 77, erthrocytesedmentation rate (ESR ) 120, HIV serology negative, and Tumor markers was elevated (carceno embryonic antigen (CEA) $0.7 \mathrm{ng} / \mathrm{ml}$, alpha fetoprotein (AFP) 300IU/ml).

So a diagnosis of sever hypercalcemia, severe thyrotoxicosis, and pancreatitis was made. Elevated tumors markers were attributed to placental growth. The patient started on high saline infusion at a rate of $300 \mathrm{ml} / \mathrm{h}$, calcitonin $400 \mathrm{mg}$ subcutaneous injections $\mathrm{Q} 12 \mathrm{H}$, hydrocortisone $50 \mathrm{mg}$ IV Q8H, Carbimazole $10 \mathrm{mg}$ PO Q8H, propranolol $10 \mathrm{mg} \mathrm{PO} \mathrm{Q} 8 \mathrm{H}$, ceftriaxone $1 \mathrm{G} I V \quad \mathrm{Q} 12 \mathrm{H}$, metronidazole $500 \mathrm{mg}$ IV Q8H, and thiamin $100 \mathrm{mg}$ IV Q24H.A blood sample for parathyroid related protein (PTHrp)was sent to specialized centre in Germany.

On Day 2, patient improved clinically, but she remained lethargic. Blood investigations showed serum calcium 17.8, serum potassium 2.7, hemoglobin 7.5, white blood cells 19 and Vitamin D level was $4.5 \mathrm{ng} / \mathrm{ml}$. Same treatment and 1 unit Packed RBCs was given. On Day 3, patient improved significantly, became fully conscious and oriented, sitting without support, and taking orally. Investigation revealed serum calcium 12.3, serum creatinine1.7, urea 43 , serum potassium 3.8 , urine culture was negative for growth. On Day 4, investigation revealed serum calcium 10.7, serum potassium 3.3 , serum creatinine 1.6 , urea 54 , serum magnesium 0.7 , serum amylase 381 , hemoglobin 8.4 , white blood cells 25. Magnesium was replaced and hydrocortisone stopped. On Day 5, serum calcium 9.9, serum potassium 3.4, serum cratinine 1.2, and urea 50. Calcitonin was stopped. On Day 6, serum calcium 8.7 , serum creatinine 1.2 , urea 34 , serum potassium 3.4. Thiamine was stopped. On Day 7 , serum calcium 
dropped to 7.4 , serum creatnine 1.0 , urea 26 , serum potassium 2.7, Hemoglobin 9. Potassium was corrected, and the patient was shifted to female medical ward (FMW) in good condition. On Day 8 , serum calcium 7.2 (low), serum creatinine 1.0 , urea 26 , serum potassium 3.1 , serum magnesium 1.4 . The patient discharged home in good condition on oral treatment.

Patient was seen one week later in outpatient clinic with complaints of fatigue and anxiety. Investigation revealed serum calcium of 5.2 , serum albumin 2.9, serum potassium 3.2. Oral calcitriol and calcium carbonate. PTHrp (parathyroid related protein) was negative. Upon next outpatient clinic (in the same week): serum calcium 8.2 , serum albumin 2.9 serum magnesium 1.6, serum potassium 3.5.Calcitriol and calcium carbonate were continued. Subsequently during next few weeks Carbimazole, calcitriol and calcium tablets were tapered and stopped. Her thyroid function test and calcium were normal. Finally, patient delivered healthy baby girl in good conditions.

\section{DISCUSSION}

Painless thyroiditis is characterized by transient hyperthyroidism, followed sometimes by hypothyroidism, and then recovery. Synonyms for this disorder include silent thyroiditis, subacute lymphocytic thyroiditis, and lymphocytic thyroiditis with spontaneously resolving hyperthyroidism. Painless thyroiditis accounts for approximately 0.5 to 5 percent of cases of hyperthyroidism. 5,6 Factors postulated to initiate painless thyroiditis include excess iodine intake and various cytokines.

Our case presented with hypercalcemia and thyrotoxicosis. As thyroid scintigraphy was not applicable in the pregnant case, we assumed Graves' disease to be highly probable, because very few cases of painless thyroiditis during pregnancy had been previously reported. For this reason and in view of the severe thyrotoxicosis Carbimazole was started before the TRAb result was available Hypercalcemia during pregnancy or after delivery is uncommon, and mostly associated with primary hyperparathyroidism (PHPT). ${ }^{7,8}$ If unrecognized, it may increase maternal and fetal morbidity. Hypercalcemia may also develop in pregnant women due to PTH-related protein (PTHrP)-producing malignant tumors (humoral hypercalcemia of malignancy). Since PTHrP is produced physiologically in fetal and maternal tissues, hypercalcemia may occasionally develop during pregnancy, puerperium, and lactation due to excessive production of PTHrP in the placenta and/or mammary glands. In hyperthyroidism the rate of bone formation and resorption are both accelerated but the bone resorption usually predominates over bone formation. As a result, significantly higher serum calcium level could be found in some hyperthyroid patients, but usually mild $\left(<10.8 \mathrm{mg} / \mathrm{dL}\right.$ ). ${ }^{9-11}$ Rarely, the calcium level may be severe enough to cause symptomatic hypercalcemia.

Our case had severe Hypercalcemia. As parathyroid scintigraphy was not possible in pregnancy medical management was initiated for hypercalemia presuming a diagnosis of concomitant Primary Hyperparathyroidism. After few days of carbimazole therapy patient developed symptomatic hypocalcemia and she was treated with calcium carbonate and calcitriol. After few weeks carbimazole was stopped because patient was euthyroid. Calcium and calcitriol was also tapered and stopped as serum calcium normalized. A diagnosis of Silent thyroiditis was made as thyrotoxicosis was transient. Retrospectively, this patient might not have the true thyroid crisis because hypercalcemia alone can cause all the patients symptoms. Therefore, anti-thyroid medications should not be given to control her hyperthyroidism. Severe hypercalcemia was rarely reported in patients with hyperthyroidism with the highest level of $15.8 \mathrm{mg} / \mathrm{dL}$ in the previous literature. ${ }^{9}$ The excessively high level of calcium may be further explained by the patient's marked dehydration from recurrent vomiting. Transient Hypocalcemia during recovery phase in this case could have been due to calcitonin injection and concomitant vitamin d deficiency.

To our knowledge this is the first case report of Silent Thyroiditis presenting with Hypercalcemia in Pregnancy.

\section{REFERENCES}

1. Morrealo de Escobar G, Obregon MJ, Escobar del Rey F. Is neuropsychological development related to maternal hypothyroidism or maternal hypothyroxinemia ? J Clin Endocrinol Metab, 2000; 85: 3975- 3987

2. Azizi F. Treatment of post-partum thyrotoxicosis. J Endocrinol Invest. 2006 Mar; 29(3):244-7.

3. Stagnaro-Green A. Approach to the patient with postpartum thyroiditis. J Clin Endocrinol Metab. 2012 Feb; 97(2):334-42

4. Filippi U, Brizzolara R, Venuti D, Cesarone A, Maritati VA, Podestà $\mathrm{M}$, et al. Prevalence of post-partum thyroiditis in Liguria (Italy): an observational study. J Endocrinol Invest. 2008 Dec; 31(12):1063-8.

5 . Ross DS. Syndromes of thyrotoxicosis with low radioactive iodine uptake.EndocrinolMetabClin North Am 1998; 27:169.

6. Schwartz F, Bergmann N, Zerahn B, Faber J. Incidence rate of symptomatic painless thyroiditis presenting with thyrotoxicosis in Denmark as evaluated by consecutive thyroid scintigraphies. Scand J Clin Lab Invest 2013; 73:240

7. Kovacs CS, Kronenberg HM. Maternal-fetal calcium and bone metabolism during pregnancy, puerperium, and lactation. Endor Rev 1997;18: 832-872.

8. Kaplan EL, Burrington JD, Klementschitsch P, Taylor J, Deftos L. Primary hyperparathyroidism,pregnancy, and neonatal hypocalcemia. Surgery 1984;96: 717-722

9. Mosekilde L, Eriksen EF, Charles P. Effects ofthyroid hormones on bone and mineral metabolism.EndocrinolMetabClin North Am 1990; 19: 35-63.

10. Iqbal AA, Burgess EH, Gallina DL, Nanes MS,Cook CB. Hypercalcemia in hyperthyroidism: patterns of serum calcium, parathyroid hormone,and 1,25-dihydroxyvitamin D3 levels during management of thyrotoxicosis. EndocrPract 2003;9: 517-21

11. Hedman I, Tisell LE. Life-threateninghypercalcemia in a case of thyrotoxicosis: clinical features and management. A case report.ActaChir Scand 1985; 151: 487-9.

Source of Support: Nil. Conflict of Interest: None Declared. Copyright: ( ) the author(s) and publisher. IJMRP is an official publication of Ibn Sina Academy of Medieval Medicine \& Sciences, registered in 2001 under Indian Trusts Act, 1882.

This is an open access article distributed under the terms of the Creative Commons Attribution Non-commercial License, which permits unrestricted non-commercial use, distribution, and reproduction in any medium, provided the original work is properly cited.

Cite this article as: Homaid Alsahafi, Bandar Damanhuri, Faizal Ahmed, Faisal Almalki, Dhyaa Mokhtar. Painless Thyroiditis Presenting as Hypercalcemia in Pregnancy: A Rare Case Report. Int J Med Res Prof. 2016; 2(6):161-62. DOI:10.21276/ijmrp.2016.2.6.033 